\title{
PENINGKATAN KOMPETENSI PEDAGOGIK GURU DALAM MEMBUAT ALAT PERAGA PEMBELAJARAN MELALUI WORKSHOP KKG SEKOLAH DI SD PANGGANG
}

\author{
Oleh: Parjiyatmi \\ SDN Panggang, Bambanglipuro, Bantul \\ Email: yatminik@gmail.com
}

\begin{abstract}
This study aim to improve the teacher paedagogic competence in making learning instrument through the workshop of teacher task-force group at SD Panggang, Bambanglipuro, Bantul, at academic year of 2017/2018. This study was conducted in two cycles. Subject of the study were class teachers and subject teachers at SD Panggang, Bambanglipuro, Bantul. The study consisted a series steps, i.e. planning, action, observation, and reflection. Data collected by using observation technique and giving an assignment in the workshop. The data then analyzed by using comparative descriptive technique. Result of the study showed there were $30.36 \%$ academic supervision finding in the workshop of teacher task-force group in SD Panggang, Bambanglipuro, Bantul, at academic year of 2017/2018.
\end{abstract}

Keywords: teacher task-force group, workshop, learning instrument.

\section{PENDAHULUAN}

Pembelajaran adalah suatu kegiatan yang bernilai edukatif. Nilai edukatif mewarnai interaksi yang terjadi antara guru dan anak didik. Interaksi yang bernilai edukatif dikarenakan kegiatan pembelajaran yang dilakukan. Guru dengan sadar melakukan kegiatan pengajarannya secara sistematis dengan memanfaatkan segala sesuatunya guna kepentingan pembelajaran.

Guru selalu berharappada saat pembelajaran apa yang sudah disampaikannya dapat diterima dan dikuasai murid secara tuntas. Hal ini merupaka masalah yang cukup sulit dan biasanya dirasakan oleh sebagian besar guru. Kesulitan itu dikarenakan anak didik bukan hanya sebagai individu dengan segala keunikannya, namun mereka juga sebagai makhluk sosial dengan latar belakang yang berbeda. Paling tidak ada tiga aspek yang membedakan anak didik satu dengan yang lainnya, yaitu aspek intelektual, psikologis, dan biologis.

Ketiga aspek di atas diakui sebagai akar permasalahan yang melahirkan berfariasinya sikap dan tingkah laku anak didik di sekolah, hal itu pula yang menjadikan berat tugas guru dalam mengelola kelas dengan baik. Keluhan guru yang sering terlontar adalah tentang pengelolaan kelas, yang akan berakibat tujuan pengajaran yang sulit untuk dicapai.

Hal ini tidak perlu terjadi, karena usaha yang dapat dilakukan masih terbuka lebar. Salah satu caranya dengan meminimalkan jumlah anak didik di dalam kelas. Mengaplikasikan beberapa prinsip pengelolaan kelas. Pengelolaan Kelas adalah upaya lain yang tidak bisa diabaikan begitu saja. Pendekatan terpilih mutlak dilakukan guna mendukung pengelolaan kelas. Disamping itu juga, perlu memanfaatkan beberapa media dan alat peraga yang telah ada atau sengaja diadakan demi terwujudnya tujuan bersama.

Salah satu hal yang tidak kalah pentingnya dalam pembelajaran adalah alat peraga yang digunakan guru. Jika materi yang diajarkannya bersifat abstrak perlu sekali dibantu dengan hal hal yang bersifat kongkrit. Alat peraga tidak harus membeli dengan harga mahal. Kreatifitas guru perlu dikembangkan demi menunjang keberhasilan dalam pembelajarannya. Misalnya bisa saja alat peraga dibuat hanya dengan barang bekas yang mudah didapat di lingkungan sekitar. 
Berdasarkanuraian diatas maka judul penelitian ini adalah: "Peningkatan kompetensi guru dalam pembuatan alat peraga pembelajaran melalui workshop KKG sekolah di SD Panggang tahun Pelajaran 2017/ 2018"

\section{METODE PENELITIAN}

Penelitian Tindakan Sekolah ini dilaksanakan di SD Panggang, UPT PPK Bambanglipuro kabupaten Bantul, Daerah Istimewa Yogyakarta Tahun Pelajaran 2017/1018 semester II. Penelitian Tindakan Sekolah ini dilaksanakan mulai bulan Februari sampai dengan bulan April 2018, Subyek penelitian Guru kelas sebanyak 9 orang, dan guru mata pelajaran sebanyak 5 orang. Jumlah peserta didik ada 199 orang. Fokus didalam penelitian ini pada materi pokok Peningkatan kompetensi guru dalam pembuatan alat peraga melalui workshop KKG sekolah.

Dalam penelitian ini menggunakan spiral dari Kemmis dan Taggart yang dikembangkan oleh Stephan Kemmis dan Robbin Mc Tanggart yang dikutip oleh Sukardi (2004: 214) yang terdiri dari dua siklus dan masing- masing siklus menggunakan tindakan yaitu perencanaan, tindakan, observasi, dan refleksi dalam satu spiral yang saling terkait.

Setelah dilakukan langkah ke-empat yaitu refleksi dan ternyata siklus 1 ditemukan permasalahan- permasalahan baru, maka siklus 2 akan diadakan perbaikan perbaikan dalam perencanaan atau tindakan atau pada saat observasi sesuai dengan kebutuhan.

Demikian halnya pada siklus 2, setelah dilakukan refleksi dan ternyata pada siklus 2 ini hasilnya penelitian belum menunjukkan kriteria keberhasilan seperti yang telah ditetapkan, maka akan diadakan perbaikanperbaikan pada langkah- langkahnya sesuai permasalahan yang ditemui dan akan dilanjutkan ke siklus berikutnya sampai tercapainya kriteria keberhasilan yang telah ditetapkan oleh peneliti.

\section{HASIL PENELITIAN \\ Prasiklus}

Pada langkah perencanaan peneliti mengadakan pertemuan dengan guru-guru yang akan diteliti, menyampaikan kondisi awal kemampuan pedagogik mereka tentang pelaksanaan pembelajaran yang ditunjang oleh adanya alat peraga. Kondisi awal mereka $90 \%$ mereka belum menggunakan alat peraga pada saat pembelajaran. Dalam melaksanakan supervise akademik Kepala Sekolah mempersiapkan berbagai kelengkapan yang akan digunakan dalam penelitian, diantaranya: 1) instrument yang akan didiskusikan dalam kelompok KKG yaitu pemetaan KD, Perencanaan alat peraga yang digunakan dan Alat Penilaian Kemampuan Guru (APKG) yang digunakan sebagai alat ukur kemampuan guru dalam pembelajaran. Pembuatan 1. Tabel observasi, 2. Lembar pengamatan dalam kerja kelompok, dan 3.Test

\section{Siklus I}

Hasil nilai untuk observasi terhadap guru dalam Workshop KKG pembuatan alat peraga diperoleh nilai 7 , dengan predikat masih 43,75\%. Mereka belum memenuhi target. Subyek yang diteliti dimana peneliti mengobservasi guru-guru (subyek penelitian) dalam membuat alat peraga pembelajaran yang disesuaikan dengan rencana pelaksanaan pembelajaran yang telah dipersiapkan, observasi dengan mendata dan menyiapkan bahan yang digunakan dalam pembuatan alat peraga, dan langkah- langkah yang ditempuh dalam pembuatan alat peraga. Langkahlangkah tersebut untuk melihat ketercapaian guru dalam pembuatan alat peraga secara mandiri dengan tidak mengandalkan alat peraga hasil produksi pabrik.

\section{Siklus II}

Pada pertemuan kali ini kerja guru sudah kelihatan mandiri, artinya setiap guru sudah aktif berusaha membuat alat peraga sesuai dengan materi yang akan diajarkan pada kelasnya. Mereka bekerja keras untuk dapat 
membuat alat peraga sesuai materi yang akan diajarkannnya.

Kemampuan pedagogik guru pada pembuatan alat peraga di siklus 2 ini naik sebesar $12,58 \%$, Jadi jika di tambah dengan siklus 1 sebesar $17,78 \%$, maka dengan dua kali tindakan dapat menaikkan sebesar $30,36 \%$, dibanding dengan kriteria keberhasilan peneliti ini yang menetapkan penelitian ini bisa berhasil jika terdapat kenaikan sebesar $25 \%$, telah terpenuhi bahkan lebih. Sehingga penelitian ini dianggap selesai dengan telah tercapainya kriteria keberhasilan yang telah ditetapkan oleh peneliti.

\section{PEMBAHASAN}

Sebaran nilai kompetensi pedagogik guru tahap awal pada saat mengajar dinilai dengan rentang 1 sampai dengan 100yang dibagi ke dalam 5 (lima) kriteria 100: $5=20$, jadi tiap kriteria menempati nilai 20 bertahap. Kriteria tersebut adalah A (amat Baik)rentang nilai $81-100$, nilai $\mathrm{B}$ (baik) rentang nilai 6180 , nilai C (cukup) rentang nilai 41- 60, Nilai D (kurang) rentang nilai 21-40, Nilai E (kurang) rentang nilai dari 1-20. Kriteria tersebut diperoleh dari penjumlahan skor dari instrument yang dikerjakan oleh guru (subyek penelitian).

Penskoran masing-masing instrument dinilai dengan 5 kriteria dengan rentang skor 1-5. Untuk mendapatkan skor 1, 2, 3, 4, atau 5 ada beberapa persyaratan yang harus dipenuhi. Setelah diketahui skornya kemudian diadakan penilaian terhadap instrument yang dikerjakan oleh subyek peneliti. Cara penilaiannya adalah skor perolehan: skor perolehan X 100. Sebagai contoh Guru A pada instrument 1 mendapat skor 3, maka nilainya adalah $3 / 5 \times 100=60$. Berarti nilai guru A pada instrument 1 adalah 60. Setelah diketahui nilai masing- masing instrument kemudian dijumlahkan sehingga didapati nilai kompetensi pedagogik guru pada pembuatan alat peraga. Contoh Guru A, nilai instrument 1 adalah 60, dan nilai instrument 2 adalah $80,60+80=140$. Nilai perolehan kemudian dibagi dengan nilai maksimal. Misal $140 / 200 \times 100=70$. Maka guru A dalam kemampuan pedagogik pembuatan alat peraga termasuk kriteria $\mathrm{C}$.

Kelebihan dari pembuatan alat peraga ini adalah guru menjadi lebih kreatif untuk menciptakan alat peraga dalam pembelajaran yang sudah dirancang, guru lebih menguasai materi yang akan diajarkannya, efisien biaya yang dikeluarkan sekolah untuk pembelian alat peraga, penggunaan bahan bekas dapat ditingkatkan. Sedangkan terdapat juga kekurangan dari pembuatan alat peraga ini, antara lain memerlukan waktu yang relative lama untuk persiapan sampai akhir pembuatan alat peraga, jika guru kurang kreatif, hasil alat peraga jadi kurang menarik.

Setelah diketahui sebaran nilai kompetensi pedagogik pada pembuatan alat peraga, kemudian dikomparasi dengan cara menjumlahkan nilai kriteria masing- masing guru kemudian dicari rata-ratanya (jumlah nilai semua guru).Contoh: guru $\mathrm{A}$, guru $\mathrm{B}$, dan guru $\mathrm{C}$ mendapatkan nilai masing- masing 60 , + Guru D,E,F,G mendapat nilai masing masing $75+$ Guru $\mathrm{H}$, dan guru I, dan Guru J mendapat nilai masing- masing 80 , perhitungannya $(3 \times 60)+(4 \times 75)+(3 \times 80)=645$. Kemudian hasil ini dibagi dengan jumlah guru $(645 / 10=64,5)$, berarti hasil komparasi kompetensi guru pada pembuatan alat peraga di siklus tersebut 64,5. Dengan dikomparasi akan diketahui berapa \% besaran kenaikan nilai kompetensi pedagogik guru dalam membuat alat peraga dari kondisi awal (pra siklus), setelah siklus 1, sampai setelah dilaksanakannya tindakan pada siklus 2 .

Kondisi awal kompetensi guru pada pembuatan alat peraga pelajaran ada 2 guru mendapat kategori Baik atau 14, $3 \%, 5$ orang guru pada kategori Cukup atau 35,7 \%, dan 7 guru pada kategori kurang atau 50,0\%.

Setelah siklus 1 pertemuan 1 , terlihat ada 4 guru yang mendapat kategori Baik atau $28,5 \%, 6$ guru termasuk kategori Cukup atau $42,8 \%$, dan 4 guru yang masih pada kondisi 
kategori Kurang atau 28,5\%. Berarti sudah kelihatan ada peningkatan.

Setelah siklus 1 pertemuan 2, terlihat ada 5 guru yang mendapat kategori Baik atau $35,7 \%, 7$ guru termasuk kategori Cukup atau $50 \%$, dan 2 guru yang masih pada kondisi kategori Kurang atau 13,3\%. Berarti sudah kelihatan ada peningkatan.

Setelah siklus 2 pertemuan 1 , terlihat ada 2 guru masuk kategori Amat baik atau A prosentase 14,28 ada 6 guru yang mendapat kategori Baik atau 42,85\%, 6 guru termasuk kategori Cukup atau 42,85\%, dan tidak ada lagi guru kategori Kurang atau 0\%. Berarti sudah kelihatan ada peningkatan lagi.

Setelah siklus 2 pertemuan 2, terlihat ada 3 guru termasuk kategori Amat Baik (A) atau $21,42 \%$, ada 6 guru yang mendapat kategori Baik atau 42,85\%, 5 guru termasuk kategori Cukup atau 35,71\%, dan tidak ada lagi guru pada kondisi kategori Kurang atau $0 \%$. Berarti sudah nampak banyak peningkatan.

Sedangkan hasil komparasi tingkat kompetensi pedagogik guru pada pembuatan alat peraga kondisi awal pencapaiannya 44,93 setelah siklus 1 meningkat pencapaiannya menjadi 62,71 atau sebesar $17,78 \%$, adapun setelah siklus 2 meningkat pencapaiannya menjadi 75,29 , atau sebesar $12,58 \%$, Sehingga jika dijumlahkan hasil komparasi siklus 1 dan siklus 2 didapatkan peningkatan sebesar $30,36 \%$.

\section{KESIMPULAN}

Berdasarkan hasil penelitian dan pebahasan dari pelaksanaan siklus 1 dan2 tentang bagaimana melalui Workshop KKG Sekolah dapat meningkatkan kompetensi guru dalam pembuatan alat peraga di SD Panggang pada semester 2 tahun pelajaran 2017/2018, diperoleh kesimpulan bahwa kompetensi pedagogik guru dalam pembuatan alat peraga dapat ditingkatkan melalui Workshop KKG Sekolah. Diharapkan setelah adanya penelitian ini guru semakin meningkatkan kompetensi pedagogiknya, yang tentu saja akan sangat berpengaruh positif terhadap peningkatan prestasi peserta didiknya.

Penerapan Workshop KKG Sekolah dilakukan untuk meningkatkan kompetensi guru dalam pembuatan alat peraga. Workshop KKG sekolah di SD Panggang dalam rangka peningkatan kompetensi guru dalam pembuatan alat peraga dilakukan melalui langkah perencanaan, pelaksanaan, observasi, dan refleksi. Tindakan perbaikan dilaksanakan dalam 2 siklus, sebagai berikut:

Tindakan pada siklus 1 diterapkan kerja kelompok guru dalam 2 kategori, yang pertama kelas besar atau tinggi (guru kelas 4, 5 dan 6) dan kelas rendah (kelas 1, 2, dan 3). Mereka kerja kelompok membuat alat peraga sesuai pemetaan materi dan langkah- langkah yang telah dibuatnya. Dikarenakan pada kondisi awal belum semua guru dalam mengajar menggunakan atau membuat alat peraga, maka pada siklus 1 ini Workshop ini langsung memetakan materi yang mungkin ditunjang dengan alat peraga dan dilanjutkan dengan pembuatan alat peraga.Dengan tindakan yang dilakukan pada siklus 1, ternyata terjadi peningkatan kemampuan guru dalam pembuatan alat peraga, dari kondisi awal didapatkan hasil rata-rata kemampuan guru 44,93, setelah siklus 1 ini meningkat 17,78. Dinyatakan sementara, karena pengukuran instrument inimemenuhi kriteria keberhasilan seperti yang ditetapkan oleh peneliti, untuk itu penelitian dilanjutkan pada siklus 2 .

Pada saat refleksi setelah siklus 1, ditemukan bahwa subyek penelitian meskipun sudah bisa membuat alat peraga dalam kelompoknya namun masih banyak kekurangan diantaranya belum sesuai dengan langkah- langkah pembuatan alat peraga yang dirancangnya.

peneliti memberikan masukan berupa solusi berkaitan dengan kesulitan- kesulitan yang dihadapi oleh kelompok kerja, dan memberikan kesempatan pada guru untuk memberikan masukan (tanggapan) solusi yang 
bisa dilakukan untuk membantu guru yang mengalami kesulitan.

Hasil pembuatan instrument setelah siklus 2, dengan perbaikan- perbaikan seperti yang telah diuraikan di atas, ternyata mengalami peningkatan. Rata-rata hasil kemampuan guru menjadi 75,29, dan prosentase peningkatan dari siklus 1 sampai 2 jika dijumlahkan telah memenuhi kriteria keberhasilan yang ditetapkan oleh peneliti adalah mencapai peningkatan minimal $25 \%$, dari kondisi awal. Penelitian ini pada siklus 1 terdapat peningkatan sebesar $17,78 \%$, dan dilanjutkan siklus 2 terdapat peningkatan $12,58 \%$, Sehingga jika dijumlahkan hasil komparasi siklus 1 dan siklus 2 didapatkan peningkatan sebesar 30,36\%, lebih banyak $5,36 \%$ dari kriteria yang ditetapkan peneliti.Sehingga dinyatakan bahwa melalui Workshop KKG di SD Panggang dapat meningkatkan kompetensi guru dalam pembuatan alat peraga.

Workshop pembuatan alat peraga akan dapat berhasil dengan baik bila mempertimbangkan beberapa hal, antara lain pada saat kerja kelompok peneliti harus mengenali karakteristik guru, sehingga masing-masing kelompok terdapat guru yang memiliki kemampuan lebih dari guru lainnya baik dari segi pengetahuan maupun kemampuan memimpin. Sehingga dalam diskusi, dan kerja kelompok tersebut ada seseorang yang dapat menjadi pemandu.

Peneliti sendiri harus terlebih dahulu mampu membuat alat peraga, akan lebih mendukung lagi jika peneliti sudah membuat contoh alat peraga yang sesuai dengan materi yang telah dipilih, sehingga dapat digunakan untuk sampel dalam praktek pada kelompok Workshop KKG di sekolah.

Peneliti sebaiknya selalu mengawal guru agar pembuatan alat peraga ini tidak hanya saat dilaksanakannnya penelitian ini saja, namun dilaksanakan secara konsisten setiap tahun pelajaran berjalan. Sehingga akan memupuk kreatifitas guru, melengkapi hasanah alat peraga buatan guru, peningkatan penggunaan alat peraga saat pembelajaran, yang akhirnya akan berakibat positif yaitu peningkatan prestasi siswa.

\section{DAFTAR PUSTAKA}

Arikunto, Suharsimi. (2006). Penelitian Tindakan Kelas. Jakarta: Bumi Aksara, 2006.

Djamaroh, Syaiful Bahri dan Aswan Zain. (2006). Strategi Belajar Mengajar. Jakarta: Rineka Cipta.

E. Mulyasa. (2002). Kurikulum Berbasis Kompetensi: Konsep Karakteristik dan Implementasi. Bandung: Remaja Rosda Karya.

El Khuluqo, Ihsana. (2017). Belajar dan Pembelajaran. Yogyakarta: Pustaka Pelajar.

Pidarta, Made. 1992. Pemikiran Tentang Supervisi Pendidikan. Jakarta: Bumi Aksara.

Sudjana, Nana. (1989). Dasar-dasar Proses Belajar Mengajar. Bandung: Sinar Baru Algensindo. 